\title{
Video activism as political advocacy for social justice: the legacy of professor Anne Smith in education
}

\author{
Michael Gaffney ${ }^{1 *}$ (D) and E. Jayne White ${ }^{2}$
}

\author{
* Correspondence: \\ michael.gaffney@otago.ac.nz \\ ${ }^{1}$ University of Otago, Dunedin, New \\ Zealand \\ Full list of author information is \\ available at the end of the article
}

\begin{abstract}
The power of video as a route to activism is not new to education. Its efficacy in galvanizing political action and advocacy concerning important social issues plays an important role in raising public consciousness and a 'call to arms'. In the early 1980's Anne Smith understood this more than most. Her use of video as a mode of political advocacy was part of a larger intellectual and political quest to alter public perspective and policy concerning women and children in Aotearoa New Zealand at that time. Since her death in 2016 the videos she made in the 1980s to early 1990s have now been made freely available to the public and continue to be relevant today. Back then they were produced and disseminated through hours of labour with a group of supporters who shared an understanding of the importance of video to galvanise political consciousness and action. This paper explores the thinking behind the production of these videos and their impact in the public domain with the help of Anne's life-long partner John Smith and then goes on to look at subsequent work. The paper then goes on to consider, with Professor Anne Meade, the strategic potential for video in the field that can learn much from Anne Smith's legacy. Together they highlight the power and potential of video to mobilise policy and practice concerning children in the public realm as agentic citizens and to progress the important work Anne started through such modalities into the future.
\end{abstract}

Keywords: Video, Activism, Early childhood education, Advocacy, Women, Policy

\section{Introduction: Video activism as political advocacy}

Video activism as political advocacy for social justice is a field of scholarship that emerged during the 1960's alongside a wider social activist movement that was characterized by the desire to bring marginalized thought and practice to public awareness. As part of this enterprise, video activism sought to "discover and recover repressed voices and ideas from the past, as well as to create and legitimate opportunities for the views to under-resourced peoples and perspectives to be expressed, disseminated, and heard" (Jansen, 2011, p 3). In many cases such advocacy was generated out of grassroots members of a community who have identified the challenge; and then presented it as video documentary to the public and policy-makers (Gregory et al., 2005). Through such means video has demonstrated efficacy in mobilizing political

(c) The Author(s). 2018 Open Access This article is distributed under the terms of the Creative Commons Attribution 4.0 International License (http://creativecommons.org/licenses/by/4.0/), which permits unrestricted use, distribution, and reproduction in any medium, provided you give appropriate credit to the original author(s) and the source, provide a link to the Creative Commons license, and indicate if changes were made. 
consciousness and, by association, advocating and promoting greater awareness about important contemporary social issues.

As a young feminist academic in the 1970's, Anne Smith (see Fig. 1) seized the opportunities such a mechanism offered for challenging existing (and we would argue residual) inequalities concerning women and children. She recognized that her ground-breaking work as a published scholar, though important, was not enough to secure a change in the wider public and political consciousness. Video, however, offered Anne a secondary route - not instead of the genre most privileged by the academy through scholarly text, but as an alternate yet complementary means of connecting research with the important issues of the day. Anne used film to raise public awareness about key issues concerning gender and, by association the rights of women in the workforce. From these early experiences Anne developed an associated interest in the rights of children to high quality early childhood education (ECE), which

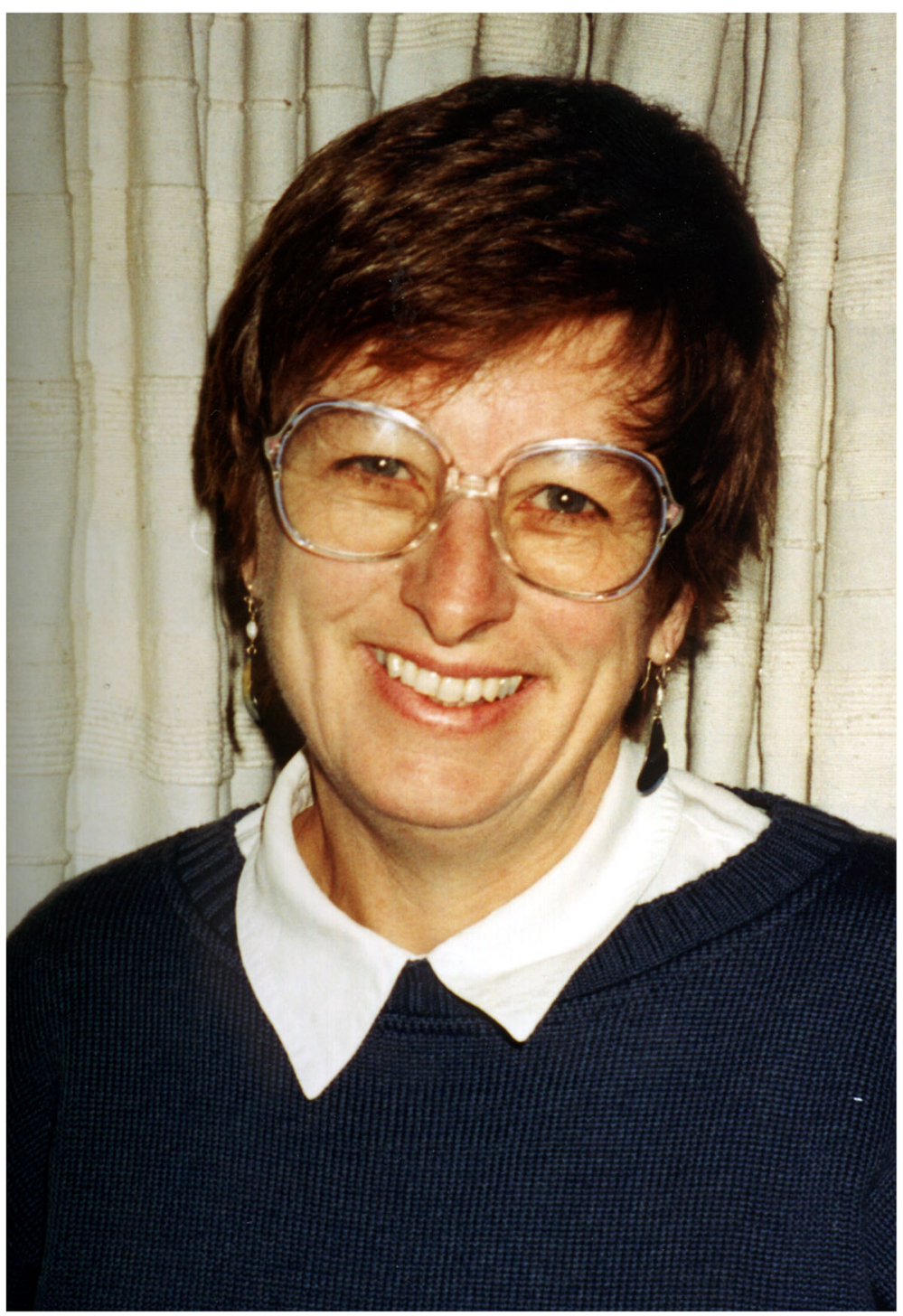

Fig. 1 Anne Smith (1940-2016) (Permission received from J. Smith) 


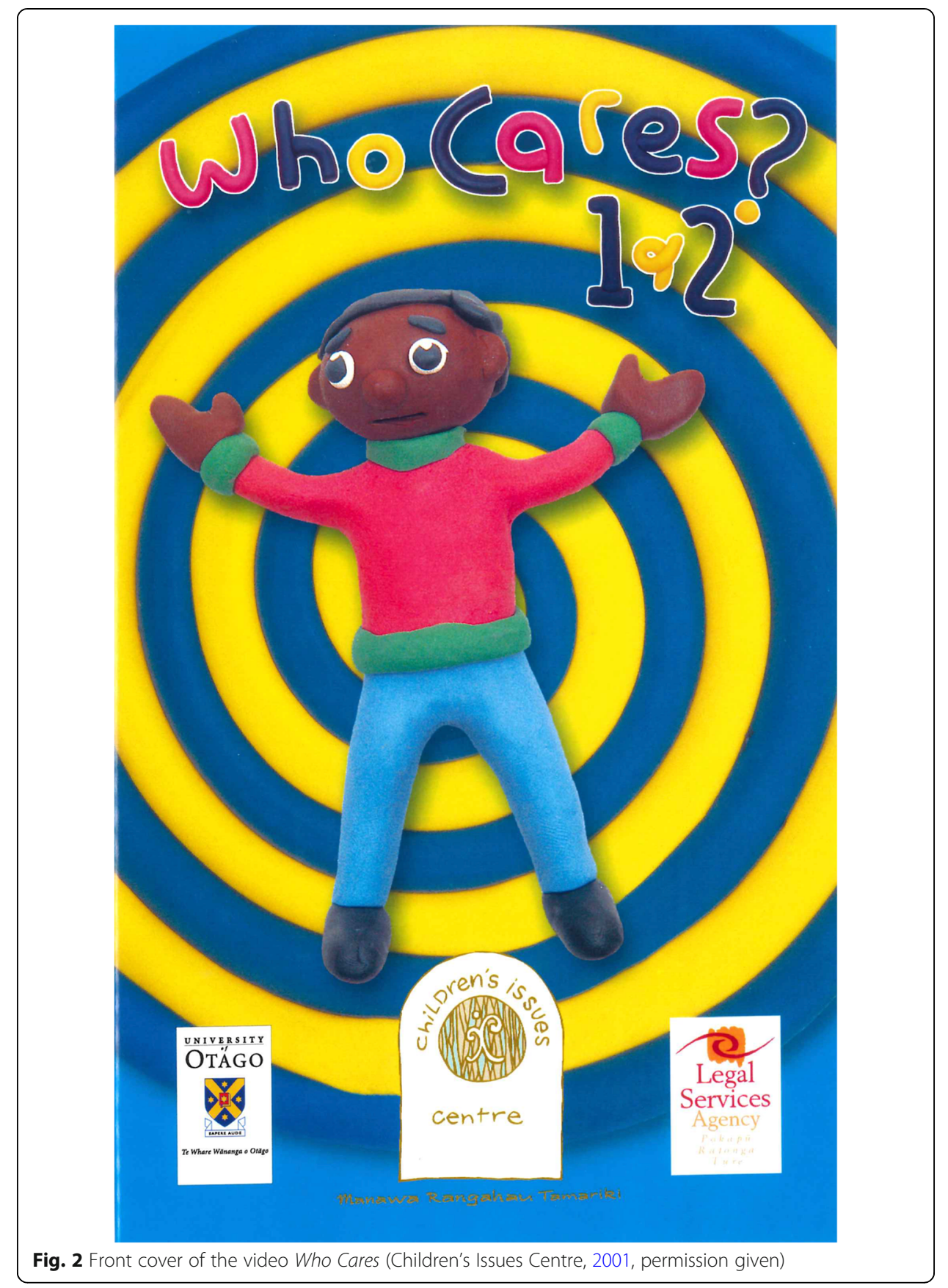

was to form the basis of a series of videos that played no small part in altering the policy environment for New Zealand families, children and teachers.

\section{Video, the academy and public policy: women and children}

It was this "push and pull between theorizing, research, and activism" (Gallagher, 2011, p. 134) through video as a catalyst for political advocacy that characterized the work of Anne Smith. She understood - better than most - the need to exploit a variety of genre to communicate research in order to have an impact. Through such means Anne forged new pathways for women's agency and social reform. For her, this was much more than an academic 
exercise. Anne had experienced first-hand the effects of gender discrimination - both as a working mother of two girls and as a devoted scholar - with serious concerns about the barriers created as a consequence. Her 1981 film Blue for a girl (Smith \& van der Vyver, 1981) fueled bystereotypical views of gender in New Zealand, though now dated by its resolution and some of the filming techniques, introduces gender themes that are still relevant today.

What arose from this early foray into video - for Anne and her colleagues at the time - was the need to politicize the issues that arose from such limiting views and which profoundly impacted upon their daily lives (May, 2017a). For Anne it was work that, as a mother herself faced with lack of access to quality early childhood education, called upon her own community - collaborating with friends and colleagues in a mutual quest for bringing about recognition of key issues affecting them all. Nichols (2001) describes using film in this context as "a cinema of empowerment" (148), which seeks to both contribute to social movements for change while at the same time building grassroot communities that could speak back to hierarchies dominating the social landscape. Through such enterprise Anne, with others, constructed an organic and empowered 'new woman and child' - an identity which came to be represented in the New Zealand early childhood movement that still exists today (May, 2017b) and which called upon social justice ideals that actively work to bring this about (Dalli, 2016).

Arising from what colleague Helen May often describes as "those heady days" (2017a) Anne forged a political agenda for childcare as a legitimate option for mothers who also wanted to work. She did so partially through a combination of well-placed scholarly publications and presentations; but it was the strategic use of video, as John Smith explains, that really brought these ideas into the public arena: (view Additional file 1: Interview with Dr John Smith).

\section{Advocacy for children through video: a series of political events}

Fueled by her earliest endeavours, Anne set a course for the production of a series of videos that responded to a persistent political disregard for quality ECE (Smith \& Milan, 1978; Smith \& van der Vyver 1981; Smith, 1983; Smith \& van der Vyver, 1993). Anne's research had revealed a series of important features that underpinned high quality experiences and practices in the field (Smith et al., 1996). The last of the four videos in the series produced Early Childhood Educare: The search for Quality (Smith \& van der Vyver, 1993) - a video that was released as part of a campaign for quality ECE being led by the Combined Early Childhood Union in 1993 (Dalli, 2016). This occured at time when a new government was rolling back planned changes to improve the quality of ECE in New Zealand, yet its plans started years earlier as evidenced by the inclusion of the keynote speakers Lillian Katz and Anne Stonehouse when they were at the 1991 Early Childhood Convention in Dunedin. The use of international experts to reinforce the arguments being made was a common strategy across Anne's films so as to highlight their academic and research foundations and grant them further credibility.

Gregory et al. (2005) describe the importance of a strategic distribution of video in order that it might have its fullest effect as an advocacy mechanism. In this Anne was an astute learner, maximizing the impact of this footage within both community and policy platforms. Nichols (2001) suggests that the power of video for activism lies in the interface between individuals and society as a whole, and a keen awareness of the hierarchies, ideologies and politics that shape practice and policy. It was not by chance 
that Anne and her colleagues sent her video to politicians on the cusp of policy decisions that impacted directly on the issues she wished to raise. Later the Search for Quality video was redited into a 22 min version and is still shown in teacher education courses to this day.

Anne's long-time friend and collaborator - also an activist in the field - Professor Anne Meade, describes this strategic orientation in the clip that follows: (view Additional file 2: Interview with Professor Anne Meade).

To extend the story, when Anne Smith went on to become the inaugural director of the Children's Issues Centre in 1995 she did not continue to produce films in the same way, but instead used collaborative strategies to continue her work. For example, in collaboration with Mary Philips who produced New Zealand television shows for children, Anne, Nicola Taylor and Michael Gaffney joined a large working party that produced the early childhood resource Amazing Me (Kids TV, 1999), building on the format of the television show You and Me featuring Suzy Cato. As well as Anne and Nicola taking roles in the project's advisory group she had Michael work on an evaluation of a pilot of the programme to enhance its rigour by using research. This involved running early programmes through a kindergarten community to see how children and families responded to content that was reasonably sensitive (Ellis et al., 1998).

At about the same time Anne had been leading a research team that was talking to children in foster and kinship care (Smith et al., 1999). Funds were raised to produce a video for children so that they were better informed about what happens to them as they transition into care. The challenge was how to use children's voices to acknowledge what children were telling the researchers, when it would be difficult, practically and ethically, to ask children to speak or act in front of a camera. Mary Phillips was able to produce and direct this work in claymation and then Michael Gaffney and Trisha Meagher Lundberg were able to trial it with some children to see what they thought (Children's Issues Centre, 2001) and determine the best way to package the video Who Cares 1 \& 2 (see Fig. 2) to improve engagement (Children's Issues Centre, 2001).

Another video project was to record the views of young people at one of the conferences arranged by the Children's Issues Centre so that the messages being created could go beyond those who were able to attend the event (Children's Issues Centre, 2003). This approach of using children's voices to provide advocacy was one of the key themes from the Sociology of Childhood (Smith et al., 2000) to engage both children and adults. Video was ideal for communicating with children and hearing from them in a way that academic writing found difficult to do. The conferences were a key opportunity to bring international visitors to Dunedin and Judith Duncan, another team member of the centre, took up Anne's idea of interviewing the early childhood visitors on film and then using these as resources when teaching students in the Postgraduate Diploma in Child Advocacy.

In all of the projects above and as stated by John Smith and Anne Meade in their respective videos, Anne Smith was always keen to share knowledge from research in some form of video genre. And so one of the longer running media programmes that Anne and others at the centre were involved with was providing the basis for SKIP Strategies with Kids and Information for Parents (www.skip.org.nz). In an effort to remove the legal option for parents to use physical discipline on their children the centre conducted a literature review for the Children's Commissioner (Smith et al., 2005). The 
outcome of this work was six principles of effective discipline that then formed the basis for the SKIP programme, which continues to make material available to both parents in an effort to support children's rights not to be hurt or mistreated as highlighted in United Nations Convention on the Rights of the Child article 19. The web resource includes many examples of children's voices in video (Family \& Community Services, 2015).

Anne retired as Director of the Children's Issues Centre in 2006 and continued working on the repeal of Section 59 of the Crimes Act 1961 that was achieved in 2007, which removed the statutory defense of using reasonable force to correct children (Durrant \& Smith, 2011). Anne stepped up her writing after retirement. Since Anne and her colleagues began working with the notion of children's voices (Smith et al., 2000) in the mid nineties it took another 20 years before it was accepted as a core feature of social work practice for those working in the new Oranga Tamariki - The New Zealand Ministry for Children (Modernising Child Youth and Family Expert Panel, 2015) that is responsible for children in state care. This clearly epitomizes Jansen's (2011) definition of activism that can "create and legitimate opportunities for the views to under-resourced peoples and perspectives to be expressed, disseminated, and heard" (p. 3) and establishes childhood voices at the heart of political reform. Her legacy lives on in this regard.

\section{0 years later}

The technology of video production has changed hugely since Anne began using film 40 years ago. Its location within social media is in no small way a feature of its changing utility for education and pedagogy (Peters \& White, 2016). The digital space is becoming the go to respository for "information". Academic publishers, Open Access and the libraries of tertiary institutions have recognized this and created a digital spaces for video research to appear and Google Scholar has created the means to find it. A search on youtube.com for child advocacy will produce over half a million hits. Yet searching for "listening to children's voices" only produces 20 thousand hits and many of those listed first comprise adults talking about the topic on behalf of children. While that might suggest that children are yet to upload their own video, we ask why should we expect children and young people to upload their voices into adults defined spaces for scrutiny? Perhaps there is more work for us to do in contemplation of more recent video technologies and modes of production at our disposal that challenge the 'work of the I/eye?' in an era of collective intelligence (White, 2016; Peters \& White, 2016)?

Yet, as Anne Meade (2017) reminds us, we can do too much talking to ourselves. She challenges us to re-define our narrative with children going forward. She offers a few models in this regard including the recent work of Reggio who have produced video containing children's thoughts, questions and dialogues on the world through art; and the ECEC CARE research which contains raw data of educational practice in seven European countries. The increase in video-oriented research in the early years provides strong impetus to consider how it might be galvanized for political and adversarial purposes (White, 2017a). In this there are many challenges ahead. Which compelling images and documentry do we present, present collectively and present publically? How do we avoid colonizing others in our quest? (White, 2017b). Anne Smith's legacy has shown us how to think about and undertake research disemination, especially in relation to closing the gap between Academics and Professionals in the move to support evidence-informed practice and political engagement. Her work reminds us that social 
movements cannot be left to the professionals (or children for that matter) alone, and so we must look at how contemporary research narratives can be shared with the public at large. In a globalized world, there is much potential for these to be shared as a source of provocation and insight - as video methodology in its own right. However, as Anne 's legacy reminds us, through video these narratives are much more than entertainment and, if treated with genuine advocacy and strategic attention in the public space, have the potential to change lives for the better.

\section{Conclusion}

Anne Smith's academic life contains a theme of finding ways to disseminate the research, often to the professional and private groups or families who often do not always have direct access to it. The Children's Issues Centre provided the vehicle to do this work. Once the research had been conducted the conferences and seminars became the first point of disemination, followed by publications including the journal Childrenz Issues. After this the Centre offered post graduate courses for those professionals wanting to gain a more structured and indepth look at the ideas that were emerging from research and had direct relevance to their work with children and young people. Anne offered a narrative that reinforced the position that research should make a difference. She became very good at bringing people together around different projects to share in that narrative through the use film and video as a galvanizing force. Her legacy offers an important route to future advocacy for children and their families - the work has only begun in this regard as societies continue to deny them voice or, within the academy, bury these important messages in texts that do not reach those who need to hear. Through video, there are increased possibilities for scholarship of the kind that does not rest with academic discoveries in text, but takes seriously the implications of research findings into the real world as a source of insight and empowerment. This is an activist agenda that binds together the researchers, the researched and those who have the power to change the world as a consequence of these insights.

Emeritus Professor Anne B. Smith was the inaugural Director of the Children's Issues Centre at the University of Otago in Dunedin, New Zealand. There are a number of online tributes that describe her life and acknowledge her contribution to academia and beyond (Taylor 2016; May 2017a).

\section{Additional files}

Additional file 1: Interview with Dr John Smith. (MP4 416864 kb)

Additional file 2: Interview with Professor Anne Meade. (MP4 431252 kb)

The authors wish to acknowledge the contributions of Professor Anne Meade and Dr. John Smith for agreeing to contribute their video segments for the paper. Their insights have helped us to bring the powerful and enduring legacy of Anne Smith - video activist - to life. Consent for their publication is available. 


\section{Authors' contributions}

Both writers contributed equally to the article. Both were involved in writing and interviewing for the purposes of including video interviews. Jayne framed up the article and Michael took it through submission. Both authors read and approved the final manuscript.

\section{Competing interests}

The authors declare that they have no competing interests.

\section{Publisher's Note}

Springer Nature remains neutral with regard to jurisdictional claims in published maps and institutional affiliations.

\section{Author details}

${ }^{1}$ University of Otago, Dunedin, New Zealand. ${ }^{2}$ University of Waikato, Hamilton, New Zealand.

Received: 4 April 2018 Accepted: 9 May 2018

\section{Published online: 05 June 2018}

\section{References}

Children's Issues Centre (2001) Who cares? 1 \& 2. The Very Useful Picture Company, Dunedin New Zealand.

Children's Issues Centre (2003) Speak out: a documentary about youth participation. Children's Issues Centre, Dunedin New Zealand.

Dalli C (2016) Research, policy and adocacy in the early years: an introduction. In: Dalli C, Meade A (eds) Research, policy and adocacy in the early years: writing inspried by the achievements of professor Anne smith. NZCER, Wellington New Zealand.

Durrant JE, Smith AB (eds) (2011) Global pathways to abolishing physical punishment: realizing children's rights. Routledge, New York.

Ellis J, Gaffney M, Phillips M (1998) Amazing me pilot evaluation. Children's issues Centre research report submitted to early childhood development. University of Otago, Dunedin New Zealand.

Family \& Community Services (2015) Children's Voices. Strategies for Kids: Information for Parents. https://www.youtube. $\mathrm{com} /$ watch?v=54WEl_mCkTg.

Gallagher M (2011) Introduction: feminism and social justice: challenging the media rhetoric. In: Curry-Jansen S, Pooley J, Tab-Pervizpour L (eds) Media and social justice. Palgrave, New York.

Gregory S, Caldwell G, Avni R, Harding T (eds) (2005) Video for change: a guide for advocacy and activism. Pluto Press, London. Jansen S (2011) Media, democracy, human rights, and social justice. In: Curry-Jansen S, Pooley J, Tab-Pervizpour L (eds) Media and social justice. Palgrave, New York.

Kids TV (1999) Amazing me (Vol 1-5). Safer Streets Trust, Wellington New Zealand.

May H (2017a) Anne B. Smith 1940-2016: the passing of a great friend, a great scholar and a great advocate for the rights of women and children. Early Childhood Folio 21(1):3-4. https://doi.org/10.18296/ecf.0034.

May H (2017b) Documenting early childhood policy in Aotearoa New Zealand: political and personal stories. In: Miller L, Cameron C, Dalli C, Barbour N (eds) The SAGE handbook of early childhood policy. SAGE, London.

Meade A (2017) Keynote speech to the new Zealand Association for Research in education early childhood special interest group hui. University of Waikato, (November 19) Hamilton, New Zealand.

Modernising Child Youth and Family Expert Panel (2015) Expert panel final report: investing in New Zealand's children and their families. Ministry of Social Development, Wellington New Zealand.

Nichols B (2001) Introduction to documentary. Indiana University Press, Bloomington \& Indiananapolis USA.

Peters M, White EJ (2016) The video journal and visual pedagogies: in the age of visual cultures. Video Journal of Education and Pedagogy [Video]. https://doi.org/10.1186/s40990-016-0008-x.

Smith AB, Milan M (1978) We can't afford to be casual about child care (27 min) University of Otago. Dunedin New Zealand. https://www.youtube.com/watch?v=mR1DQpbjnBU.

Smith AB, van der Vyver R (1981) Blue for a girl (38 min) University of Otago, Dunedin New Zealand. https://www. youtube.com/watch?v=TrzsYVuzkbo.

Smith AB (1983) Dunedin Family Daycare Project (18 min) University of Otago, Dunedin New Zealand. https://www. youtube.com/watch?v=OQ7XVYqdRfk.

Smith AB, van der Vyver R (1993) Early childhood educare: The search for quality (38 min) University of. Otago, Dunedin New Zealand. https://www.youtube.com/watch?v=4ov7ePgLihA.

Smith AB, Ford VE, Hubbard PM, White EJ (1996) The quality of childcare for infants in New Zealand. State-of-the-art monograph. No. 4. New Zealand Association for Research in Education, Palmerston North New Zealand.

Smith AB, Gollop M, Taylor N, Atwool N (1999) Children's voices in foster and kinship care: knowledge, understanding and participation. Journal of Child Centred Practice 6(1):9-37.

Smith AB, Gollop M, Taylor N, Marshall K (2005) The discipline and guidance of children: messages from research - a review of research literature for the Office of the Children's commissioner by the Children's issues Centre. University of Otago, Dunedin New Zealand.

Smith AB, Taylor N, Gollop M (eds) (2000) Children's voices: research, policy and practice. Longman, Auckland New Zealand.

Taylor NJ (2016) Tribute to emeritus professor Anne B. Smith (1940-2016). http:/www.otago.ac.nz/cic/study/ otago620482.html. Accessed 5 Mar 2018.

White EJ (2016) A philosophy of seeing: the work of the eye/I' in early years educational practice. J Philos Educ 50(3): 474-489. https://doi.org/10.1111/jope.2016.50.issue-3/issuetoc.

White EJ (2017a) Featured editorial: what ethical challenges do researchers face with videos and children? Video Journal of Education and Pedagogy https://videoeducationjournal.springeropen.com. Accessed 15 Jan 2018.

White EJ (2017b) The 'work of the eye' in infant research: a visual encounter. In: Li L, Quinones G, Ridgway A (eds) Studying babies and toddlers: relationships in cultural contexts. Springer, Dordrechdt The Netherlands. 